\title{
CHOOSING PROPER RELATIONSHIP BETWEEN TEACHER AND STUDENTS: INTERPERSONAL, CONTRACTUAL AND PEDAGOGICAL RELATIONSHIP
}

\author{
Dameanus Abun, Ph. D ${ }^{1 *}$, Theogenia Magallanes, Ed. $D^{2}$ \\ ${ }^{* 1}$ Divine Word College of Vigan, Philippines \\ ${ }^{2}$ St. Benedict College of Northern Luzon, Philippines
}

*Corresponding Author: -

\begin{abstract}
: -
Choosing proper relationship is an important matter to be considered particularly in the school setting. Education is intellectual and character and spiritual formation. All kinds of relationship must be tailored toward such aim. The relationship between teachers and students must help the students grow intellectually and spiritually or morally. Based on my presentation, the nature of the relationship between teachers and students must be pedagogical in nature, asymmetrical relationship or between the unequal. The teacher is there to help the students learn and grow intellectually and spiritually.
\end{abstract}

Key words: - Interpersonal, contractual, superficial and pedagogical relationship 


\section{INTRODUCTION}

Teachers are often called heroes. They are in the front line of helping citizens become functional members of society. They are not paid much but their job is the most important in laying the foundation of a great nation. Without teachers, man cannot fully be developed as a human and functional human in society. Thus the job of a teacher is not just simply to teach and fill the empty head of the students with a lot of information which may not be relevant to the life of students but the job goes beyond teaching. It is also about building a proper relationship to develop other aspect of human life.

Learning can happen not only by accumulating knowledge they receive from teachers inside the classroom but through relationships or associations with their teachers or the adult. Many things can be learned through informal relationship. Character formation cannot be just developed through information that they get from teacher in their class, but it is through modeling or example that teachers is showing to their students. Thus the behavior of teachers matters much to the moral development of students.

Effective teaching is often time not measured by how well the teacher prepares the subject but how well teachers live their life based on what they are teaching and they relate their life to the life of students. Thus a teacher is not only in the classroom but it extends beyond classroom. Their whole life must influence and touch the life of students. It happens only in the relationships. Thus the relationship goes beyond the wall of classroom. In such case teacher has to be open and available anytime to help the students outside the classroom, anywhere and anytime when the students need them.

Since teachers are teaching not only the things that they learned from the books but also through their life example which they reveal in the relationship, thus the question for a teacher is how and what kind of relationship that they need to develop with the students. Since the issue is the relationship between teacher and students, thus the relationship may not be any kinds of relationship. Thus, we need to explore different kind of relationship that may or may not help the students. We need to know these different relationships in order for us to know the nature of man and to know what kind of relationship that a teacher must develop with the students.

\section{Interpersonal relationship: A relationship between equals or symmetrical relationship}

Interpersonal relationship is an association between two or more people that may range from fleeting to enduring. This association may be created by different reasons such as having a common interest, having a regular business interaction, love, like and some other type of social commitment. The persons who go into interpersonal relationship believe that through such relationship, certain aspect of their needs can be satisfied. In this case, two participants are interdependent, where the behavior of each affects the outcomes of the other. This kind of relationship can take place in a great variety of contexts, such as school, a community and a relation between teachers and teachers, teachers and students, in the workplace, clubs, and other forms of association. Kelley, et.al (1983) define a close relationship as "one that is strong, frequent, and with diverse interdependence that lasts over a considerable period of time".

Interpersonal relationship is established by voluntary act and therefore it is not structured or regulated and there are no external forces to set the rule of engagement but only the persons who are in the relationship. If the reasons for their relationship are met or not met, then naturally the relationship may continue to grow or disappear. Thus, the length of such relationship is unpredictable since only the individual person can measure if his/her needs have been or have not been fulfilled yet by such relationship (MSG, n.d).

Why does human need relationship? Relationship is originated from our very nature as a social being. House, et al. (2003) argued that interpersonal relationships are vital and important to the physical and mental health of individuals. As a social being, humans have a natural need and tendency to relate themselves to other human beings. They depend on other human being to fulfill certain needs and to be able to grow. In such case, humans may not be complete without other humans. It is only by living with other humans, that they can perfect themselves. Decy and Ryan (2000, pp. 68-78) have identified one of innate psychological needs which is relatedness need. The natural desire to connect to others and to grow then is a matter of fact built in every human person.

Social nature of human creates dependence. Dependence on others is not only in terms of physical needs but also psychological needs. As an individual person, he/she cannot fulfill all his physical/psychological needs by himself/herself, but he/she needs other people to fill the gap. One of the psychological needs is recognition. As a social being, he or she needs to belong to the group and be recognized. Abraham Maslow perfectly described hierarchy needs of human beings as physiological, safety and security, belongingness, self-esteem, and selfsatisfaction needs (Stoner, 2000, McShane, 2000). After Maslow, Clayton Alderfer as cited by McShane (2000) also supported the idea of Maslow that humans have three different needs such as existence, relatedness and growth needs. Relatedness needs is the same with belongingness needs of Maslow that human as social being needs to relate himself or herself to other people. It is a deep human need to relate and to belong to a group, to be accepted and to be recognized. The same theory of needs is also presented by John W. Atkinson as cited by Stoner (2000). Atkinson argued that humans are motivated by needs for achievement, need for power, and need for affiliation or close association with others.

Human beings are innately social and are shaped by their experiences with others. Such innate social need motivates an individual to relate himself or herself with others and such need must be satisfied because it will continue to push the person to fulfill it until it is fulfilled. There are multiple perspectives to understand this inherent motivation to interact with others. In fact, the need to belong is so innately ingrained that it may be strong enough to overcome physiological and safety needs, such as children's attachment to abusive parents or staying in abusive romantic relationships. Such examples illustrate the extent to which the psychobiological drive to belong is entrenched. Baumeister and Leary (1995) had already argued that the need to belong is a fundamental human need. They further explained that satisfying this need requires frequent, and positive interactions with the same individuals and must be long term. It is considered imperative to establish long term relationship with a limited number of people is important. 
The theories that we have pointed out are just indicating that interpersonal relationship is born out of human needs. Those are basic needs that must be realized for a person to grow as a human being and a social being. Those needs can only be realized by establishing relationship with other human beings. Beside fulfilling and satisfying innate social needs, persons who enter into an interpersonal relationship are driven by certain benefits. Good interpersonal relationship brings satisfaction to both sides of people (UK, 2013) Therefore, the benefits are mutual, not only one side. Individuals seek out rewards in interactions with others and are willing to pay a cost for said rewards. It is in this case, people are willing to sacrifice other things in order to maintain the relationship. People could not afford to lose a beautiful relationship because it would be considered a lost on both sides.

Studies also pointed out that persons who are going into interpersonal relationship are not just simply to meet their physical needs but as we have emphasized human are social creature and as such there is a need of attachment, a need to be loved. Insel (2001) argued that attachment requires sensory and cognitive processing that lead to intricate motor responses. As humans, the end goal of attachment is the motivation to acquire love, which is different from other animals who just seek proximity. Based on his study, there is neurological basis for attachment and further emphasized that pro-social emotions and behaviors are prerequisite for a healthy relationship. The social environment, mediated by attachment, influences the maturation of structures in a child's brain. This explains how infant attachment affects adult's emotional health.

Based on what Insel (2001) pointed out in his study, we cannot deny then that teachers and students are all social animal, then there is a need to be associated with or to belong to, in short, the need for attachment. Hence, a logical consequence of such argument then challenges the school and teachers to promote a healthy interpersonal relationship with their students. Promoting such kind of relationship may help students grow mature not only as an individual person but also as a social person. However, one need to be reminded that interpersonal relationship is a symmetrical relationship, a relationship between the equals. Both are there to share their life and to enrich one's lacking needs. In this case both are growing together and learn from each other. Therefore, this kind of relationship is applied appropriately between adults, and not between an adult and a child. Such presentation indicates that interpersonal relationship may not be proper in the relationship that teachers develop with elementary, junior or high school students. Such kind of relationship may be applied to higher years in college, depending on the maturity level of the students.

\section{Contractual relationships: Business Relationship, Superficial and Impersonal}

Before going into defining the relationship between teacher and students, whether to choose contractual relationship or not, one needs to understand the nature of contractual relationship.

Business Dictionary defines contractual relationship as "a legal relationship between contracting parties evidenced by (1) an offer, (2) acceptance of the offer, and a (3) valid (legal and valuable) consideration". It is legally enforceable agreements, and any party, person or organization that enters into a contract has a contractual relationship with the other parties. When a party enters into a contractual relationship, it agrees to certain conditions and responsibilities and failure to adhere to them may constitute a breach of contract. One can only exercise his/her task based on the stipulated contract, nothing more, nothing less.

There are three things for a contract to exist: an offer, acceptance and validity. A party is offering a product or services and the second party is accepting the offer. To make the agreement valid and binding, the contract has to be written and signed by both parties which stipulate the duties and responsibilities of both parties. Once it is signed and notarized by public attorney, then contract is legally enforceable. Violating the contract is tantamount to a breach of contract and can lead to the cease of relationship or court litigation. The relationship emanated from contract is functional (Markgraf, 2018). The relationship exists as long as both parties are doing their functions stipulated in the contract. Both parties are bound by the law to implement what has been agreed upon. The focus is the content of the contract and the services to be delivered. There is no human relationship. Any actions done by both parties are only superficial and it is done to enhance the functional relationship.

Applying such kind of relationship between the teacher and students means that the relationship is established because there is an offer or product to be sold to the students and the students, after some analysis of cost and benefit, accept the offer or purchase the product. Students enroll and pay the tuition fees and the school assigns teachers to teach. Both parties (school/teachers and students) are only allowed to do their duties and responsibilities within the prescribed contract. Teachers must teach because they are paid by the students and students should attend classes. Violating the contract means the relationship ceases to exist. Teachers are doing their duties as teachers which is to teach while students pay tuition fees for their salaries. The problems of whether the students are listening and understanding their subjects are no longer the concern of teachers. If students listen and understand then they can pass. If, however they do not pass, then they may either be terminated or may be advised to repeat the subject/s. The concerns of why students do not understand and do not pass the exam are no longer their concern. Looking into the reason behind students' failure and fixing the problem are beyond their functions. No concern for the students. Just do the job as demanded by the contracts (Albu, n.d, Quizlet, n.d). There is a rule of engagement to be followed by both parties.

Such relationship implies that knowledge is a commodity. It is like many other things like oil or other products. It is a commodity, widely used and widely available for sale (Adam, 2013). The teachers are only to deliver the knowledge or information and the students listen and pay. It is only by listening that they can understand and gain some skills and therefore their investment can have some return. If they do not listen and understand, they lose their investment. It is clear then that it is no longer the problem of teachers why students failed.

Following such line of thoughts, the relationship between teachers and students are business relationship. There are several types of business relationship. First, technical relationship. In this kind of relationship, the buyer recognizes that the seller's product is good or better than the competitor. There is no personal rapport between the buyer and seller. The 
danger here is that the buyer can go away once there is a better alternative. Second is social relationship. This relationship is friendly but superficial. The relationship may be friendly, but their conversation does not touch business issues. Lastly, partner relationship. This is the relationship in which the buyer trusts the seller. The buyer knows that the seller is there to help them. The buyer gets the value out of the interaction with the seller. As a result, the buyer would like to stay with the seller (Related Vision, n.d). The teachers are producers or sellers and students are customers or buyers. The focus of teachers is how to produce quality product or services so that they can retain the loyalty of the students for them not to go away. The teachers make everything possible to retain the students. The teachers' concerns are preparing their lesson and delivering it well in the class with the purpose of retaining the students. This is the only way how to maintain their customers' loyalty. All activities done by the teachers are only to attract the students to enroll their subject and they can have money in return.

Relationship is just superficial and impersonal. Superficial means "skin deep" or existing on the surface. Teachers are superficially charming, but it is not coming from within. Teachers may converse with the students but there is no solid foundation of their talks (Psychologynet, 2016). Words are said but there is no deep meaning in it. Teachers become narcistic because they are charming to draw people to themselves. They fake their emotions. Smiling, laughing and talking with the students are not sincere because in this kind of relationship is just a business strategy to have a personal attachment with the customer and to retain them not to go away and enrolling in other subjects or other school. The relationship is between the subject and object. Teacher is the subject and students are object. Students are used so that the teachers can teach and earn their living.

What we have mentioned is being practiced in the school environment in the postmodern education. Education is a commodity and is no longer an instrument of character development. It was lamented by Lyotard (1979) that there has been a significant change in the teacherstudent relation. This is now no longer seen as a pedagogical relationship but a contractual one. Students, in paying ever higher fees for the privilege of attending an educational institution, expect good value for their (private, self-interested) investment. When the services they 'purchase' do not measure up to their expectations then it can be threatened with legal action for breach of an implied contract. He further reminded the institutions tertiary institutions must be 'accountable' for what they do, and when they fail to 'deliver the goods', they should pay a (legal and/or financial) price for this.

In conclusion we may argue that contractual relationship is not a proper relationship to be developed between teachers and students because in such a relationship, students are treated as customers, buyers and not as persons who have the personal needs such as physiological and psychological needs. Those needs cannot be fulfilled or satisfied if there is no pedagogical relationship.

\section{Pedagogical relationship}

Before going deeper into our discussion on pedagogical relationships, I want to share my own experience in secondary education. When I was in secondary education, the subject that I hated most was English subject. Every time a teacher came to the class, I felt nervous because he was used to punish the students who could not give the right answer in English when he asked questions. What made it worse was the fact that it was not only English subject that was being feared but also the teacher. The subject was hard and the teacher was hard. I was afraid to ask questions because the teacher might punish me again if I asked the wrong questions. I was not going any further in my subject, the ignorance continue to rule. I almost quitted but for the sake of finishing my study, I endure the situation.

Things changed when I was in second year level of secondary school. The teacher for English subject was changed. He was an ex-seminarian. He encouraged students to ask questions and correct the mistakes but did not punish the students. The feeling was that it was ok to make mistakes. The excitement was growing. Not only that, he allowed us to ask question anywhere and anytime. He was always ready to answer us. Such openness allowed us to develop relationships. I became friend to him and he helped me a lot in my English subject. I was no longer afraid to ask questions and to make a mistake because I know that he was there to guide me. The result of such relationship was that I love English subject and I was always longing to see my English teacher. Not only love the subject but I usually confide my personal problems to the teacher and he was there to listen and to guide me. Such a wonderful experience inspired me a lot and may the teacher rest in peace.

The experience that I shared is just a simple application and explanation of pedagogical relationship. The pedagogical relation refers to special kind of personal relationship between teacher and student or adult and child that is different from other interpersonal relationships. This pedagogical relation is discussed more recently in English by Manen (1991). Manen thinks that to be an educator is at least partly based on the ethical responsibility to offer oneself constantly to be available to the child as a kind of instrument or mechanism. Thereby the educator is assumed to act in such way that s/he produces the results that s/he immediately feels (believes) the child to intend in his/her own action. It is not about conscious calculation, but a task that opens up to the educator as an immediate requirement and responsibility. This relation between child and parent/teacher is symbolized by 'living with the child in loco parentis'. Manen means by this the normatively loaded interaction between adult and child which is permeated by the adult's responsibility to take care of the child's life and growth into a responsible person.

As we have discussed above, teachers are holding a big responsibility. The job is not only to master the subject and deliver it correctly with the correct strategy of teaching. It takes more than knowing the content to be a good teacher. Teachers are not only in words but also in action, especially in their behavior in dealing with the students. One of the most important aspects of teaching is building relationships with their students. Teacher-child relationships influence how a child develops. The relationship can relate to a wide range of school adjustment outcomes, including liking school, work habits, social skills, behavior, and academic performance. 
When teachers have open communication with their students, that is inside and outside the classroom, they are transmitting not only knowledge but also values that student need in their life. As Stonkuvienè ( 2010) emphasized that when we communicate with each other we are not only transmitting messages, but also enriching experiences, perceiving emotions and cultivating attitudes, values, ways of being with others and the world. We are co-building people. Educational context is a privileged environment for communication, particularly interpersonal communication. Postic (2008) criticizes theorists who support the study of teaching on the forging of "teaching machines" and underrate the interpersonal influences of the pedagogical context, as supported by Rogers (1985) and other authors. In a dialogical and teleological human sense of education, communication is a transversal element to all cultures. Communicating is a bio-psychosocial act; conducted by the body, it involves personalities, roles and emotions.

The relationship may not be symmetric but asymmetric; it is a relationship between unequal, teacher and students. Teacher and students are not really equal friends and their relationship is a relationship of an adult and a child. Therefore in such a relationship, teacher is still teacher who is in the presence of students who need help and guidance. As M.G. Pietyin (2013) pointed out that your students are not your friends. She is right because there's a certain responsibility in a pedagogical relationship. A teacher must never confide to a student or look to a student for emotional support. It is perfectly appropriate for a student to do these things, however, with a teacher. A teacher stands in loco parentis. Most college students are young people who have not yet made their way in the world but who are going to college as part of their preparation for that. They are more than their student numbers. They are inexperienced adults who occasionally need support and guidance when contemplating life's larger questions, or simply how to survive a term in which they are taking too many courses in order to minimize their student-loan debt.

It has always been emphasized that to be an effective teacher is not a matter of knowing the subject very well but it is more than that, it is more on our approach to students, how we view and deal with the students. Students come to school with their different situations, they are not coming to receive the information from the teacher which they can get it in the internet but they are looking for something that could change their life and it may not be given through the lectures but through our behavior that we show them every day. The subjects that they learn every day may not inspire them and bring them happiness, it is not even helping them to become mature person in the future and help them in their pursuit of "the good life" in the classical sense. But that can be done only by teachers who are willing to engage with their students as human beings and who can draw on their own humanity, and not simply their intellects, in those relationships.

The call of duty as teacher is not easy after all. The job is going beyond preparing class and teaching well. Ordinarily, nobody likes to occupy their time entertaining students who come to your office just to see their good teachers. No one likes to worry about the life of other people but the call of duty as a teacher reminds all teachers that it is one one's duty to build a pedagogical relationship with the students. They may not learn values and good behavior in the classroom but they learn it when they are dealing with their teachers. They cannot confide the personal problems and aspirations in the classroom, in front of other students, but they can confide their life through their relationship with their teachers. Listening to their aspirations and desperations will inspire them to define their own life of what kind of life they are going pursue. Teachers need to know their students because by knowing them, teachers know how to deal and help them. As Noddings (2007) pointed out that teacher must know about students' prior experiences and build on them with new learning experiences. He continued that as the child's teacher, you know more about the child than the writers of the book you are teaching from. You can adjust the way you teach based on how your students learn and what they take interest in. The curriculum and content being covered will be much more meaningful if delivered in a way the students favor. Teaching methods would be enhanced by a curriculum that contribute to the relevance and interest level of students work and learning experiences. When students are forced to go through material that they are not engaged in they will lose interest. Students need to connect with what they are learning through engagement. Curriculum approaches that combined social as well as emotional intelligence of students are much more effective (Noddings, 2007).

As a summary on the idea of pedagogical relationship we may point out some characteristics that mark the difference between interpersonal relationships. In the pedagogical relationship, the adult is directed toward the child and the relation is asymmetrical, a relationship between unequal. The adult is there for the child and the child is not there for the adult. The purpose of such kind of relationship is to help the child grow becoming a better person in the future. This kind of relationship ends when the child grows up and matures.

\section{Conclusion}

After discussing three kinds of relationship, now we know what kind of relationship that a teacher needs to develop with their students. Relationship is a need, and it is not only true to the adult or teachers but also child or students. All have needs to be able to relate themselves to one another. It is a social needs and it is inborn. Because of such inborn needs, building up interpersonal relationship is the fulfillment of such needs and it is a must. But this kind of relationship is between adult or symmetrical relationship, between the equals, because both are there to fill the vacuum of each individual's needs. There is mutuality and reciprocity. Should you consider this kind of relationship? The message is clear that this relationship is between the equals.

The solution is not even to take contractual relationship as a replacement. This kind of relationship is business relationship, superficial and impersonal. Therefore, contractual relationship has no place in educational context, though; it may be prevalent in the postmodern education as lamented by Lyotard (1979). Such kind of relationship is considered as subject and object relationship. Both are using each other for individual interest at the expense of the other.

Therefore, interpersonal relationship and contractual relationship may not be qualified for the relationship between adult and the child or teacher and students. It has to be pedagogical relationship, a relationship that is educational in nature, a 
relationship that is oriented toward the growth of the child. It is asymmetrical, relationship between the unequal. The teachers are there to help the students. It is the student who is in need of teacher.

\section{References}

[1].Adams, M. (2013). Knowledge is a Commodity. The Relationship Economy: Technology and the Human network. Retrieved from http://www.relationshipeconomy.com/2013/04/knowledge-is-a-commodity/

[2].Albu, C. (n.d). Types of relationship between Teachers and Students. (Slide Presentation). Retrieved from https://www.slideshare.net/ecaterinaalbu/types-of-relationships-betweenteachers-and-students

[3].Baumeister R. F., \& Leary M. R. (1995). The need to belong: Desire for interpersonal attachments as a fundamental human motivation. Psychological Bulletin, 117, 497-529.

[4].Essays, UK. (2013). Principles for good interpersonal relationship. Retrieved from https://www.ukessays.com/essays/young-people/principles-for-good-interpersonalrelationship-young-peopleessay.php?vref=1

[5].House, J. S., Landis, K. R., \& Umberson, D. (2003). Social Psychology of Health. In: Salovey, P. \& Rothman, A. J. (Eds.), Social Relationships and Health. New York: Psychological Press, pp. 218-26.

[6].Insel, Th. (2001). The neurobiology of attachment". Nature Reviews Neuroscience. Retrieved from http://www.neurosciencereview.com

[7].Kelley, H. H., Burscheid, E., Christensen, A. (1983). Close Relationships. New York: Freeman

[8].Lyotard, J.F. (1979). The Postmodern Condition: A Report on Knowledge. London and New York: Routledge:

[9].Manen, V. M. (1991). The Tact of Teaching: The Meaning of Pedagogical Thoughtfulness. http://www.maxvanmanen.com/biography/ retrieved, September 8, 2014.

[10]. Markgraf, B. (2018). Contractual Relationship in Management. Chron. Retrieved from https://smallbusiness.chron.com/contractual-relationships-project-management-63182.html McShane, S. (2000). Organizational Behavior. McGraw-Hill: New York.

[11]. MSG (n.d). Stages in Interpersonal relationship. Retrieved from https://www.managementstudyguide.com/stagesin-interpersonal-relationships.htm

[12]. Noddings, N. (2007). Critical Lessons: What Our Schools Should Teach. University Press: Cambridge

[13]. Postic, M. (2008). A Pedagogical Relationship. Lisboa: Padrões Culturais

$\begin{array}{llllll}\text { [14]. Psychologynet. (2016). What } & \text { is } & \text { Psychology. }\end{array}$

[15]. https://www.whatispsychology.net/what-does-superficial-mean/

[16]. Pietyin, M.G. (2013). The Pedagogical Relationship on Teaching. DREXEL UNIVERSITY. Retrieved from http://mgpiety.org/tag/the-pedagogical-relationship/ Quizlet (n.d). Contractual Relationship.

Retrieved from https://quizlet.com/14411691/contractual-relationships-flash-cards/

[17]. Ryan, R.M., \& Deci, E.L. (2000). Self-Determination Theory and the Facilitation of Intrinsic Motivation, Social Development and Well-being. American Psychological Association, Vol. 55, No. 1, pp. 68-78.

[18]. RelatedVision. (n.d). Type of Business Relationship. Retrieved from http://www.relatedvision.com/Building-Relationships/business-relationships.html

[19]. Stoner, J A., Freeman, F., Edward. G., \& Daniel R. (2000). Management. Upper Saddle River, New Jersey: PrenticeHall.

[20]. Stonkuvienè. (2010). Communication as an essential element of pedagogical process. London: Methuen \& Co. 